821.134.2(82).08 Борхес Х. Л.

81 '38

https://doi.org/10.18485/sj.2018.23.1.37

ЈЕЛИЦА В. ВЕЉОВИЪ ${ }^{*}$

Универзитет у Крагујевцу

Филолошко-уметнички факултет
Оригинални научни рад

Примљен: 04. 01. 2018.

Прихваћен: 29. 01. 2018.

\title{
ФИГУРЕ ХАРМОНИЧНОГ ПРОТИВРЕЧЈА КАО ОСНОВЕ СТИЛСКОГ ИЗРАЗА У ФАНТАСТИЧНОМ РЕАЛИЗМУ ХОРХЕА ЛУИСА БОРХЕСА**
}

\begin{abstract}
Рад има за циљ проналажење фигура хармоничног противррчја - оксиморона и парадокса - као основних стилистичких поступака у кратким причама Хорхеа Луиса Борхеса, које према књижевно-уметничкој тенденцији припадају правцу фантастичног реализма. Како ове Борхесове приче имају за циљ ефекат зачуђења и несигурности у представу стварности која се читаоцу пружа, рад ће настојити да укаже да се језичке основе овог Борхесовог израза налазе у поступку језичког онеобичавања и деаутоматизације коју су у теорију о поетској функцији језика увели руски формалисти. Рад се одлања на тезу да ефекат фантастичног реалног зависи од ефекта зачудности који се превасходно ослања на језичко онеобичавање кроз довођење у везу семантички противуречних појмова. Друга претпоставка на којој почива рад је да се управо довођењем у везу семантички противуречних појмова, а најчешће употребом стилских фигура оксиморона и парадокса, постиже ефекат фантастичног реализма тј. упућивање на фантастичну димензију стварности која своје референте само налази у свету читаоца, текста и маште. На овај начин ћемо сагледати како проширење могућности комбиновања језичких знакова, њиховог
\end{abstract}

*jelica.veljovic@filum.kg.ac.rs

** Треба напоменути да је за потребе овог рада издвојено пет најрепрезентативнијих Борхесових прича, иако се функција исказивања фантастичног реализма кроз фигуре оксиморона и парадокса може истражити и у многим другим причама попут: Тема о издајнику и јунаку, Смрт и бусола, Три верзије Јуде, Ибн Хакан ал Бухари, мртав у свом лавиринту, Астерионов дом, Двојник, или Пешчана књига. 
семантичког поља и успостављање логичних веза између супротних речи, упућује на основну поставку и тежњу Борхесовог фантастичног реализма - проширење стварности и њено обогаћивање људском имагинацијом. За испитивање ових могућности анализираће се примери из прича које су објављене у три збирке: „Маштарије” (Ficciones, 1944), и „Алеф” (ElAleph, 1945).

Кључне речи: фантастични реализам, онеобичавање, Борхес, парадокс, оксиморон

\section{ОД ФАНТАСТИЧНОГ РЕАЛИЗМА ДО ФОРМАЛИСТИЧКОГ ОНЕОБИЧАВАЬА}

Како бисмо приступили сагледавању фантастичног реализма кроз призму поступка онеобичавања и деаутоматизације захтеваног од стране формалиста, потребно је сагледати основне поставке овог правца у хиспаноамеричком прозном изразу. Фантастични реализам се прво појављује у Аргентини и представља „најособенији вид хиспаноамеричког реализма, поникао из индивидуалног напора да се објасни и открије стварност коју не уочавају чула”, и која „не може да се изрази кроз уобичајене језичке формулације” (Павловић-Самуровић 1993: 226).У једној однајприкладнијих дефиниција фантастичног реализма као посебног књижевног жанра, Давид Роас (2011: 8)истиче да се ради отекстовима заснованим на слободном комбиновању и изокретању елемената преузетих из стварности, при чему текст постаје метафоричка пројекција тог истог света. Дакле, текстови писани у кључу фантастичног реализма пројектују свет стварности, али не миметички, већ стилском реверзијом и ревалоризацијом референци од којих је та стварност сачињена. Стога се свет познатог види на други начин, али откривајући оно што је у његовим оквирима остало као страно, чудно или непознато. Према Роузмари Џексон (2001: 150) чудноватост јесте предуслов за настанак фантастичног текста, будући да се као услов јавља замена познатоги уобичајеног, за чудно илити непознато. И Аласраки (2001: 66) ће рећи да је фантастично оно чудно и непознатокоје продубљујечовеково виђење и доживљај света.Сматра се да текстови фантастичног реализма сведочеи о постојању другог света, односно других светова, у оквиру већ постојећег, што се постиже мешањем чудног и реалистичног (Џексон, 1986: 134), при чему је кључно изазвати снажан ефекат страности и неодлучности у читаоцу (Тодоров 2010: 20) будући да пред собом има нешто што је његовом резоновању непознато. Можемо само додати да у фантастичном реализму долази до промене означеног, будући да је означитељ убачен у нови контекст у оквиру којег добија нове семантичке слојеве.

Треба истаћи и Солдатићево (2002: 96-97) запажање да свет створен у фантастичном тексту није копија постојећег, већ продор непознатог и страног 
у познати свет, што даље повлачи раскид са његовим конвенцијама.У вези са тиме Рамирес-Пимијента (2005: 174) истиче да је фантастични реализам субверзија стварности на нивоу текста, будући да изокреће успостављени ред и тежи описивању онога што постоји „изван језика”, а што као такво и изазива ефекат страности и чуђења у читаоцу. Овиме је описана основа естетског деловања фантастике, која се заснива на избацивању читаоца из њему познатих калупа виђења и знања, нагони га на прекид са вероватним и могућим феноменима стварности, као и на спознају и перцепцију оних невероватних и немогућих које измичу логосу. Тодоров истиче да се овај књижевни ефекат фантастичног превасходно ослања на употребу стилских фигура и да настаје када читалац фигуративно значење узима као дословно. Стога као важну поставку треба истаћи закључак да фантастично пре свега произилази из језика и да од њега зависи:

„Ако се фантастично непрестано служи реторичким фигурама, то значи да је у њима пронашло своје порекло. Натприродно се рађа из језика, оно је истовремено његова последица и доказ (...) да једино језик омогућава поимање онога што је у језику увек одсутно - натприродног.” (Тодоров 2010: 79)

Означавајући сестога као субверзивна књижевност, она која уноси немир, нестабилност и назире промену реда познатих референцијала из стварности, фантастика се можепредставити као жанр који уводи свеж материјал у књижевност јер обнавља нашу перцепцију света, а са њом и речи и језик. Управо ово представља основну ставку путем које се може указати на однос фантастичног реализма и формализма, јер је обнова речи оно што је Виктор Шкловски захтевао од поетског језика у свом есеју Ускрснуће рећи из 1914. године.

Захтев за ускрснућем речи упућен је оживљавању стварности кроз уметничко онеобичавање исте, које ће пробудити речи из њихових уобичајених конвенционалних облика. Према Шкловском (1969: 17), ово је задатак уметности и језика у поетској функцији: „Стара умјетност је умрла... и ствари су умрле - ми смо престали осећати свет! Само стварање нових уметничких форми може човеку вратити доживљај света, ускрснути ствари и утући песимизам”.Стога уметнички поступак јесте „поступак зачудности”, онеобичавања, или „стварања нове напрегнуте речи, која је намењена виђењу”са циљем да пружи ново виђење ствари, изван пуког и аутоматског препознавања (Шкловски 1969: 19, 43). Ослобођење од аутоматског препознавања стварносних референцијала имплицира и ослобођење од стварности као аутоматизоване творевине, што и формалиста Медведев (1976: 132) подвлачи као циљ књижевности. Што се неких од основних формалистичких метода тиче, истичу се игра речи (Шкловски 1969: 48), које се тако могу истргнути из својих уобичајених контекста и обогатити значењима, и „противзбивање” илити развијање сижеа на основу неподударности у тексту (Шкловски 1969: 53). Овоме се може додати став Тињанова (1976: 321) да је неопходно довести познате 
ознаке у опозитни и дијалектички однос - „однос са-против-стављања”. На тај начин као да се претпоставља изградња другог референтног и семантичког система кроз онеобичену употребу језика, што се показује остваривим путем јукстапонирања речи супротних значењских категорија. На овом месту треба истаћи да формалистичко захтевање за деаутоматизацијом и онеобичавањем речи као да захтева ослањање на фигуративност језика, будући да свака фигура подразумева одређени степен одступања од уобичајене употребе језика: „Фигуративност је отклон, удаљавање од уобичајеног, дакле нешто што је неуобичајено" (Ковачевић 2000: 91).

Највећи познаваоци фантастичног реализма истичу учесталост одређених стилских поступака који функционишу као блокаде конвенционалних канала разумевања, и који нагоне читаоце на изналажење нових путева комуникације са текстом. Ти стилски поступци и фигуре јесу следећи:игра речи, при чему долази до замене реда и разградње знака ка не-значењу, а зарад указивања на његову конвенционалну природу (Џексон 2001: 147); метафора, метонимија и алегорија, уз неопходно уводно реалистично приповедање које би се пресекло ,језиком другости” (употребом тропа) и упутило у непознате делове стварности (Аласраки 2001: 278); оксиморон, као главна фигура поигравања са значењима речи (Џексон 1986: 19); јукстапозиција опозитних категорија, компарација и паралелизми(Бесијер 2001: 86). Осмотривши наведене одлике типичне за стил писаца фантастичног реализма, и поредећи исте са препорученим методама од стране формалиста, можемо закључити да је суштина фантастичног реализма онеобичавање стварности кроз фигуративну деаутоматизовану употребу језика, чиме паралелно долази до проширења поља језичких знакова и поља човековог доживљаја стварности.У истраживању функционисања ових стилских поступака на примеру одабраних прича Хорхеа Луиса Борхеса, фокус овог рада је превасходно на „фигурама хармоничног противуречја" (Ковачевић 2000: 91), оксиморону и парадоксу, као фигурама које у себи имплицирају јукстапонирање супротних и међусобно контрадикторних појмова, а зарад изградње новог значења које је само привидно нелогично. Ово истраживање ће се руководити Јакобсоновим (1966: 88) ставом да се у „Поетском делу” примењује традиционални инвентар уметничких средстава ради постизања нових циљева, а оцењивање тих средстава ће се изводити у светлу истраживања специфичне употребе језика у фантастичном реализму.

\section{БОРХЕСОВА „ЕСТЕТИКА ДЕАУТОМАТИЗАЦИЈЕ”}

Пре анализе ових стилских поступака у Борхесовим причама, неоходно је истаћи да се ради о хиспаноамеричком писцу који је признат по својој авангарднојултраистичкој поезији и причама писаним у кључу фантастичног реализма, 
који је до краја живота заокупио читаво његово стваралашатво. Пишући на граници модернизма и постмодернизма, као и под утицајем структурализма и постструктурализма у свом широком песничком и прозном опусу, Борхес се често ослања и на филозофију чији метод писања користи и коју сматра још једним књижевним жанром (Саватер 2002: 8). Стога га многи сматрају филозофом међу писцима, и писцем међу филозофима.У својим кратким причама Борхес тежи стварању светова који су фантастични и аутореферентни, који не зависе од спољашњег света да би деловали истинито, а који у својој основи баш такви jecy. Теме којима се Борхес бавио углавном су везане за бесконачност, хаос и ред, универзалност и монизам, бескрајно удвајање и умножавање идентитета, појмова и стварности, оповргавање појма времена, сагледавање књижевности као једне бескрајне књиге, поткопавање општег знања и негирање могућности људске спознаје. Према набројаним основним темама његовог стваралаштва може се рећи да се Борхес бавио различитим и чак међусобно супротним темама, иако оне у његовим причама функционишу готово напоредо и заједно. Развој Борхесовог текста упућује на систем у коме једна категорија увек прелази у своју супротност, или се испоставља да је одувек у себи сажимала своју негацију. Тако је за умножавање неопходно јединство, једно увек бива приказано као умножено, ред и хаос настају једно из другог, субјекат приче - ,ja" - је увек истовремено и „онај други”, а бесконачно се крије у коначном. Стога би се као полазна тачка у анализи његовог стила могла истаћи претпоставка да је целокупно Борхесово стваралаштво базирано на хармоничном противречју његових тематских категорија- оном које је само наизглед супротно, док у дубини својих значења јесте логично повезано и мотивисано.

Најистакнутији критичари Борхесовог дела и познаваоци његовог специфичног стила као најважније истичу употребу метафоре, алегорије, игре речи, непрестану смену знакова и значења и тежњу за стварањем књижевног текста који је затворени семантички универзум, а услед тежње за изрицањем непознатог и неизрецивог, сумње у речи и неповерења у језик за који сматра да осиромашује стварност, и на крају зарад проширења језика (Баренећеа 1953: 563-565; Гертел 1969: 33; Гонсалес 1994: 149; Алонсо 2005: 446-449). Тек се у релативно новијим студијама о његовом стилу упућује на процедуру онеобичавања стварности кроз језик и на „естетику деаутоматизације”, која је усклађена са формалистичким методама (Фајн 2000: 51; Хил Гереро 2008: 144). У том светлу значајно је истаћи да је једна од суштинских Борхесових поетичких поставки везана за тезу да језик није исто што и стварност, и да се истиноликост стварности пре налази у књижевном делу него у језику (Кастељанос 2012: 36). Због овога можемо претпоставити да Борхес тежи употреби чудних и наизглед семантички нелогичних језичких комбинација, са циљем да изазове слику нове, другачије и фантастичне стварности која би била стварнија од објективне стварности. 


\section{ОКСИМОРОН И ПАРАДОКС КАО ОСНОВЕ БОРХЕСОВОГ ИЗРАЖАВАҢА ФАНТАСТИЧНОГ}

Оксиморон је према Ковачевићу (2000: 95-96) спајање међусобно неспојивих, контрадикторних појмова, у којем на први поглед невероватни и комплексни догађаји проналазе свој прави и једини израз. Ово синтагматско уланчавање је наизглед нелогично, али се ради само о „површинској дисхармонији" будући да је тумачењем оксиморонских комбинација ипак могуће успоставити логичну везу и утврдити „унутрашњу (суштинску) хармонију” (Ковачевић 2000: 97). Будући да ће се функција оксиморона у Борхесовим причама представљати паралелно са примерима парадокса, треба подвући да Ковачевић (2000: 115) истиче да парадокс може бити дефинисан и као „реченични (или дискурсни) оксиморон” будући да подједнако почива на довођењу у везу појмова са неподударним семантичким компонентама. Парадоксалност се састоји у у томе што се на основу претпарадоксичног дела реченице најмање може очекивати оно што следи тј. што долази на крај реченице. Тај парадоксични крај је насупрот могућим очекиваним завршецима и непредодређен је семантиком претходног, тј. претпарадоксичног дела (Ковачевић 2000: 114). Можемо назначити да парадокс и оксиморон омогућавају основно функционисање фантастике Борхесових прича - упућивање на нову, онеобичену и невероватну стварност или појаве, управо стога што представљају неуобичајено спајање логички и семантички неспојивих компонената реченице, да изискују од читаоца проналажење унутрашње хармоније и изградњу нових менталних слика и значења, те да упућују на невероватне догађаје који су изван свих дотадашњих конвенција и знања читоаца. За упућивање на ове функције датих стилских фигура биће обрађене три приче из збирке „Маштарије” из 1944. године (Пјер Менар, писаи Дон Кихота, Вавилонска библиотека, Врт са стазама које се рачвају), и две приче из збирке „Алеф” из 1945. године (Захир и Алеф). ${ }^{1}$

\section{1. Пјер Менар, писац Дон Кихот (PierreMenard, autor del Quijote)}

Прича припада збирци „Маштарије” и означава се као постмодернистичка прича у чијој основи је представљање књижевности кроз феномен интертекстуалности, и у којој се излаже став да су читање и писање два једнака процеса, те да једно дело увек изнова настаје у читаоцу и у сваком засебном читању. Ова идеја која лежи у потки приче и покреће њену фабулу сама по

\footnotetext{
${ }^{1}$ Треба напоменути да је за потребе овог рада издвојено пет најрепрезентативнијих Борхесових прича, иако се функција исказивања фантастичног реализма кроз фигуре оксиморона и парадокса може истражити и у многим другим причама попут: Тема о издајнику и јунаку, Смрт и бусола, Три верзије Јуде, Ибн Хакан ал Бухари, мртав у свом лавиринту, Астерионов дом, Двојник, или Пешчана књига.
} 
себи јесте парадоксална, тако да се може рећи да ова фигура јесте основа ефекта приче. Сам наслов приче јесвојеврсни оксиморон, будући да име писца романа Дон Кихот, Мигел де Сервантес, јесте део опште познатог знања, а које се овим оксимороном изазива и подрива. Читава прича је саздана око проширеног дејства ове Борхесове оксиморонске слике, а образложена је и аргументована кроз низ парадокса:

a) У ком се негира да је састављање романа који би био идентичан већ постојећем роману (од речи до рели и од реда до реда) копирање тог истог романа, тј. изворника:

„Није желео да саставидругог Дон Кихота... већ Дон Кихота. Непотребно је додавати да му никад ни на памет није пало да механички препише изворник; циљ му није био да га копира. Задивљујуће амбициозан, покушао је да сачини неколико страница које би се поклапале - од речи до речи и од реда до реда - са страницама Мигела де Сервантеса." (Борхес 2006: 26);

б) У ком се испуњење услова бесмртности описује као лако: „'Мој подухват у суштини није тежак'...'Било би довољно да сам бесмртан па да га спроведем у дело". (Борхес 2006: 26-27);

в) У изрицању става да формално идентични тектови могу бити различити: „Сервантесов и Менаров текст идентични су у њиховом језичком делу, али је зато други готово бескрајно богатији” (Борхес 2006: 29). Ова парадоксалност је у наставку појачана идентичним цитатима из првог дела деветог поглавља романа Дон Кихот, од који један припада Сервантесу а други Менару, а који су постављени у однос супротности следећом реченицом: „Састављено у XVIIвеку, пером Сервантеса (...) ово најбрајање само је реторичка похвала историји. Менар, заузврат, пише: (...)”.

Можемо рећи да ове три основне употребе парадокса, као и оксиморон из самог наслова приче, упућују на онеобичено аргументовање и потврђивање могућности „новог писања истог”, зарад потврђивања логичних могућности радњи које наизглед могу деловати апсурдно и невероватно. Због тога ефекат ове приче и зависи од јукстапонирања супротних и различитих идеја и значења, које проналазе заједничку логику и образложење у постмодернистичким идејама о књижевном делу.

\section{2. Вавилонска библиотека (Biblioteca de Babel)}

У причи Вавилонска библиотека алегоријски се упућује на универзум као на Библиотеку, која је подељена на бескрајан низ шестоугаоних галерија које су повезане уским ходницима, а на чијим странама се налазе полице испуњене књигама. Свака књига је сачињена од истих двадесет и пет знакова (двадесет и два словна знака, проред, зарез и тачку), који носе целокупно време света. 
У причи се алегоријски одражавају Борхесово монистичко виђење света, човека и његове перцепције живота и свог смисла, времена, језика и Бога, а сви појмови које Борхес обрађује у причи усклађени су са темама вечности и бескраја, порицања времена, јединства и умножавања, и хаоса и реда. Опис ових феномена дат је у фантастичном кључу, и заснива се њиховом предочавању кроз оксиморон и парадокс, те ћемо у наставку представити на који начин ове фигуре представљају предуслов за стварање сфере фантастичних референата.

a) Оксиморон је присутан у следећим примерима: „кружна књига непрекинутог хрбата" (Борхес 2006: 48) (пример сложеногоксиморона јер је сачињен из два оксиморона: „кружна књига” и „књига непрекинутог хрбата” за указивање на могућност постојања Бога у Библиотеци); „самоједско-литвански дијалекат гуаранија са гласовним променама класичног арапског” (Борхес 2006: 50) (сложени оксиморон, будући да се упућује на спајање језика из различитих породица у јединствени језички систем, а зарад указивања на постојање језика изван познатих језичких система); „историја будућности” (Борхес 2006: 50) (зарад упућивања на тоталитет света и времена обухваћен у књигама Библиотеке); „испосничка разулареност” (Борхес 2006: 51) (којом се упућује на опсесивно трагање за почетком, крајем и суштином Библиотеке). Ови примери неки су од кључних феномена којима се описују основни феномени и функционисање Библиотеке, а њихова основна естетска функција је проширење читаочеве перцепције стварности.

б) Парадокс можемо сматрати за оксиморон проширен на ниво реченице или пасуса, прожима читаву причу, и налазимо га у следећи примерима:

- „Гробница ће ми бити несагледиви ваздух; тело ће ми пропадати дуго, дуго, пропадаће и распадати се од трења услед падања, које је бескрајно" (Борхес 2006: 48), у ком се као нелогичност јавља призор сахрањивања тела у ваздуху, где се распада од трења приликом пада кроз самиваздух;

- „Дотични мислилац установиоје да се све књиге (...) састоје из истоветних елемената... Указао је и на чињеницу коју су потврдили сви путници: у огромној Библиотеци не постоје две истоветне књиге." (Борхес 2006: 50), супротност је изражена у томе да истоветни елементи никада не могу сачинити два истоветна скупа;

- „...постоји сигурно књига која би била савршени сажетак свих осталих" (Борхес 2006: 52), у ком се супротност открива у описивању једног појма који сажима све остале сродне, при чемусвепостаје део једног;

- „Уствари, Библиотека садржи све вербалне структуре, све варијације које допуштају двадесет и пет језичких симбола, али ни један једини 
апсолутни бесмисао. Не треба ни спомињати да најбољи томови на многобројним шестоугаоницима које опслужујем за наслов имају $3 a-$ чешьљана грмљавина, Гипсани грч, Ахахахаsтlӧ” (Борхес 2006: 52).

Нелогичност овог израза се открива у супротности да су све допуштене варијације симбола смислене, и да најбољи томови књига носе оксиморонске или потпуно бесмислене наслове који не упућују на могуће референте или појаве;

- „Библиотека је неограничена и периодична. Уколико би неки вечни путник кренуо кроз њу у једном правцу, установио би након неколико векова да се исти томови понављају у истом нереду (и да овај, поновљен, тако постаје ред: Ред)" (Борхес 2006: 54), где се као парадоксалан јавља феномен реда који се успоставља као периодично поновљени хаос.

Поред наведених парадоксалних и оксиморонских аргумената и описа о функционисању Библиотеке као алегоријске слике света, треба истаћи да сваки од њих представља стилизовану пројекцију стварности кроз основне идеје аутора. Можемо рећи да једна од њих јесте потврђивање парадокса као саставног дела функционисања света.

\section{3. Врт са стазама које се рачвају (El jardín de los senderos que se bifurcan)}

Прича се делимично може сврстати у детективски жанр, будући да се ради о тајном задатку шпијунаТрећег рајха, који невероватним сплетом околности долази до открића тајног рада свог претка, Цуи Пена, на изградњи лавиринта и писању романа. Главна тема прича је оповргавање линеарног времена и потврђивање постојања више напоредних временских сфера које функционишу истовремено и у складу са човековим изборима. Време је виђено као умножено, а представљено је метафорично, као мрежа која обухвата сва времена у чудесномобиму, при чему се у опис прикључује и оксиморон: „Веровао је у... вртоглаву мрежу разилазећих, сустижућих и напоредних времена" (Борхес 2006: 63). Три придева везана за времена која ова мрежа обухвата јесу међусобно искључиви будући да се истовремено ради о њиховом међусобном разилажењу, сустизању и напоредном протицању. Када се ови придеви додатно поставе уз именицу „време”, добија се оксиморонска и персонфикована слика једног крајње фантастичног - онеобиченог - времена. Поменута концепција времена као мреже свих могућих временских токова јесте у основи Цуи Пеновог лавиринта и романа, који су у наставку приче представљени кроз парадокс. Примери за то су следећи: 
a) У исказивању идеје о могућности обухватања свих могућности и свих избори у једну целину, која се представља кроз коначне појмове - роман, лавиринт и живот: „Цуи Пен се опредељује - и то у исти мах - за све могућности. На тај начин он ствара $a^{2}$ различите будућности и различита времена, који се такође умножавају и рачвају" (Борхес 2006: 61). У супротном или нелогичном односу се налазе следећи појмови овог парадоксалног исказа: определити се/ истовремено / (за) све, стварање/ време/ различита времена;

б) Неозначавање и означавање се представљају као истоветни процеси, при чему први чак интензивира други процес: „Може бити да је управо стално изостављање једне речи и прибегавање неспретним метафорама најизразитији начин да се та реч означи" (Борхес 2006: 62-63);

в) У потврђивању постојања свих могућности у једној целини, постају могући удвајање и умножавање субјекта, који се удаљава од материјалности сопственог тела: „Учини ми се да је влажни врт око куће начичкан невидљивим особама. Те особе смо били Алберт и ја, тајанствени, ускомешани и многолики" (Борхес 2006: 63).

Може се рећи да су Борхесове основне књижевне идеје исказане кроз Цуи Пенову изградњу лавиринта, односно романа као лавиринта, а које метафорички осликавају Борхесово разумевање књижевности и књижевног текста као фантастичног простора у ком све могућности могу постојати истовремено. Притом се да видети како ово метафоричко схватање књижевности аутора функционише путем парадоксалних описа.

\section{4. Захир (EI Zahir)}

Прича припада збирци кратких прича под насловом „Алеф”, објављеној 1945. године. У овој причи Борхес развија тему универзалног монизма, који се рефлектује кроз предмет преузет из свакодневице - новчић од двадесет сентава - који у себи садржи читав познати свет. Иако је сама природа предмета оксиморонска јер је Захир „новчић-свет”, он разоткрива једну од суштинских идеја Борхесове естетике: универзални монизам, који функционише према принципу multuminparvo, тј. мноштва које је садржано у једном. Како је ово физички бескрајно мноштво физички садржано у једном коначном ограниченом предмету из свакодневице, сама природа тог новчића је промењена и парадоксална, због чега је у овој причи кључна употреба оксиморона и парадокса. Није случајност што управо у овој причи Борхес укључује сопствену рефлексију о оксиморону као фигури која настаје када се ,jедној речи додаје

\footnotetext{
${ }^{2}$ Свака употреба искошеног фонта (италика) у цитатима је у складу са навођењем изворног текста, и не представља наглашавање одређених појмова од стране аутора рада, већ самог аутора текста - Хорхеа Луиса Борхеса.
} 
(се) придев који као да јој противречи" (Борхес 2004: 66), дефинишући га кроз примере „црна светлост” и „црно сунце”, а проналазећи пример оксиморона у сопственом понашању када након бдења одлази у крчму.

Најочигледнији пример парадокса у причи Захир је изречен на самом почетку, када писац приповедањем о смрти пријатељице Теодолине Виљар пружа наизглед реалистични оквир приче: „Трагала је за апсолутним, као Флобер, али за апсолутним у тренутном" (Борхес 2004: 65). Управо овај почетни оксиморон изражава суштину приче, иако бежи могућностима нашег знања и повезивања са једним семантички јединственим језичким референтом. Оксиморон је присутан и у опису ефекта Захира на оног који га поседује: „Пре сам могао да замислим писмо а онда и главу; сада обе стране видим истовремено” (Борхес 2004: 70). Парадоксалност која ће даље кључно утицати на мотивацију фабуле налази се у следећим примерима:

a) У опису Захира као предмета који је више различитих и међусобно неповезаних предмета:

„У Буенос Аиресу Захир је обичан ковани новац од двадесет сентава; ... у Гуџерату, крајем XVIII века, Захир је био тигар; на Јави слепац из џамије ког су каменовали верници; у Персији астролаб...; у Махдијевим тамницама, око 1892, један мали компас...; у џамији у Кордоби, према Цотенбергу, жила у мермеру на једном од хиљаду двеста стубова; у јеврејској четврти у Тетуану, дно неког бунара." (Борхес 2004: 64)

б) У предочавању Захира као симбола свих новчића који прожимају људску историју и имагинацију: „Помислих да нема новчића који не би био симбол свих новчића што у бескрај светлуцају кроз историју и предања" (Борхес 2004: 66);

в) Опсесивним односом приповедача према Захиру, он запада у парадоксално стање, разапет између жеље за заборавом и потребе за његовим вечитим меморисањем: „Било је ноћи када сам са толиком сигурношћу веровао да га могу заборавити да сам га се намерно подсећао" (Борхес 2004: 68);

г) Претпоставка да је Захир слика магичног тигра на таваници ћелије, доводи до потребе за још једним парадоксалним описом насликаног предмета: „Тог тигра чинили су многи други тигрови, у вртоглавом преплету; пресецали су га тигрови, пругали су га тигрови, обухватао је мора и Хималаје и војске налик на друге тигрове" (Борхес 2004: 69). Парадоксалност овог примера се поново састоји у изједначавању једног и многих, при чему многи бивају сажети у једном. Парадоксалност овог описа је појачана појмовима море, Хималаји и војске, који су обухваћени разнородним појмом тигар

${ }^{3}$ Треба напоменути да тигар прати Борхесову машту од његовог детињства (Мангел 2005: 59-60), и да је постао један од најважнијих мотива у његовом стваралаштву, добивши функцију 
д) Закључујући о погубном утицају Захира, јунак приповедач закључује да: „По идеалистичком учењу, глаголи живети и сањати јесу, у строгом смислу, синоними....” (Борхес 2004: 70). Изједначавање глагола „живети” са глаголом „сањати” одражава утицај фантастичног предмета на то да приповедач почиње да живи само кроз сан који замењује јаву, као што на крају приче Захир замењује читаву Земљу. Барокно посматрање живота као сна јесте једна од честих тема Борхесовог фантастичног стваралаштва, која као и претходне почива на оксиморону и парадоксу.

\section{5. Алеф (El Aleph)}

У причи Алеф по којој је читава збирка добила име, Борхес као у Захиру представља предмет који у себи сажима читав свет, али је разлика у томе што се не ради о свакодневном предмету попут новчића, већ о оптичком предмету који је на граници вероватног: бљештава куглица која мења боје. Естетски принцип, ауторова идеја и тема су исте као у Захиру будући да алеф одражава Борхесов монизам и веру у постојање мноштва у једном. Стога је улога коју оксиморон и парадокс имају у овој причи једнако оцртана циљем представљања непредстављивог и фантастичног. На почетку уплива фантастичног догађаја открића алефа, након реалистичног уводног оквира приче, алеф је описан оксиморонски као: ,jедна од тачака у простору која садржи све остале тачке” (Борхес 2004: 101), а затим у наставку и као: „место у којем се налазе, одељена, на земљиној кугли, виђена са свих страна" (Борхес 2004:102). Оксиморонски описи алефа састоје се из супротстављених синтагми: једна тачка/ све тачке, једно место/ сва места, чије противуречности јесу појачанепарадоксалном описом да су све дате тачке и места истовремено и са свих страна сажети у алефу, али одељено и засебно. Оваква слика представља онеобичавање појмова „места” и „тачка”, али и буди неопходност деаутоматизоване изградње менталне слике алефа, који може бити схваћен као својеврсни хипероним, иако у себи не субординира појмове исте или сличне категорије. Занимљиво је истаћи да се на крају приче Борхес позива на математички закон трансфинитних бројева у којима целина није већа од било ког појединачног дела, чиме као да оправдава невероватност величине и бескрајног садржаја алефа. Описи алефа кроз смену оксиморона и парадокса праћени су затим и парадоксалним описима појава које алеф покреће:

својеврсног симбола. У причи Божји запис (Laescritura de Dios) из збирке „Алеф” Борхес истиче како је тигар један од Божјих атрибута, а главни јунак приче налази да је божја тајна записана на живописном крзну тигра ког овај свакодневно гледа. У познатој песми Други тигар (Elotrotigre) Борхес га метафорички представља и као систем речи људског језика. Објавио 1972. године је и збирку песама под насловом „Злато тигрова” (Elorodelostigres), у којој се тигар појављује као симбол сунца и вечности. 
а) Власник куће Карлос Данери, обузет алефом, посвећује живот писању поеме која би сажимала читаву Земљу, али на посве невероватан начин:

„Овај је умислио да устихује целокупну Земљину куглу; те 1941. већ беше обрадио неколико хектара у држави Квинсленд, више од километра речног тока Оба, гасометар на северу Веракруза, главне трговине у четврти Конспесион, летњиковац Маријане Камбасерес де Алвеар у улици Онсе де Септиембре у Белграну, и једно турско купатило у близини познатог акваријума у Брајтону.” (Борхес 2004: 98)

б) Парадоксалност алефа преноси се и на парадоксалност преношења приче о њему, који је повезан са немогућношћу адекватног комуницирања о фантастичном феномену:

„Стижем сада до неисказивог средишта своје приче; овде као писац падам у очај. Сваки језик чини низ симбола; да би се њима баратало саговорници морају имати исту прошлост; како онда другима да пренесем Алефову бесконачност, коју моје бојажљиво памћење на једвите јаде обухвата?” (Борхес 2004: 103)

Иако је страх од немогућности преношења приче о алефу исказан, опис алефа се наставља, те можемо рећи да се Борхес ослања и на парадоксалност самог језичког израза који може упутити и на оно невериватно и незамисливо, тиме и потврдитифантастично као могуће. Ова прича потврђује да Борхесово језичко поигравање и употреба појмова кроз нове и неуобичајене синтагматске односе омогућавају језичко предочавање фантастичних и незамисливих појава и предмета, који самим својим постављањем у језик потврђују вечито опстајање језичког знака између имагинарног и стварног.

Целокупна Борхесова поетика и разумевање односа стварности, језика и књижевности се често приказују сажето кроз неколицину цитата преузетих из његових прича, а чини се да у духу теме и фокуса овог рада стоји следећи ауторов парадоксални став из приче Пешчана књига, који сликовито упућује на типично борхесовски стил и структурацију фабуле: „Није могуће, али јесте." (Борхес 2009: 109). Можемо рећи да је описивање и проницање у оно фантастично као „немогуће које јесте” осликава суштинску функцију оксиморона и парадокса у Борхесовој фантастичној прози. Противречност на којој се заснивају, унутрашња семантичка хармонија на чије одгонетање позивају и проширење перцепције целокупног поља стварности указују на могућности постојања немогућег, необичног, страног и фантастичног, а које се могућим показује најпре у језику. Као да функција језика у фантастици јесте да стави сам однос језика и стварности на пробу, истичући паралелно флексибилност и креативност језика, али и креативност људског доживљаја и стварања света - и то са оне стране доксе, са оне стране језичког знака и са оне стране разума. Формалисти би можда тврдили да хармонично противречје ускрсава речи и потврђује сликовитост самог језика, изазивајући деаутоматизовано виђење и 
комуникацију као неопходне. Како Борхесов фантастични реализам то исто зазива, управо заснивајући ефекат и природу фантастичног на оксиморону и парадоксу, могло би се рећи да је његова проза хармонично противречје које као такве осликава и структуру језика, текста и стварности.

\section{ЛИТЕРАТУРА}

Аласраки 2001: J. Alazraki, „QQué es lo neofantástico?”, David Roas (coord.), Teorías de lo fantástico, Madrid, Arco/libros, 265-283.

Алонсо 2005: C. Alonso, "Borges y la teoría", $M L N, 120,2$, 437-456.

Баренећеа 1953: A. M. Barrenechea, "Borges y el lenguaje", Nueva revista de filología hispánica, 7, 3/4, 551-569.

Бесијер 2001: I. Bessiere, "El relato fantástico: forma mixta de caso y adivinianza", David Roas (coord.), Teorías de lo fantástico, Madrid: Arco/libros, 83-104.

Борхес 2004: Х. Л. Борхес, Алеф, превео Александар Грујичић, Београд: Паидеа.

Борхес 2006: Х. Л. Борхес, Маштарије, превео Александар Грујичић, Београд: Паидеа.

Борхес 2009: Х. Л. Борхес, Пешчана књига, превео Далибор Солдатић, Београд: Паидеа.

Гертел 1969: Z. Gertel, 'La metáfora en la estética de Borges”, Hispania, 52, 1, 33-38.

Гонсалес 1994: J. E. González, "Entre alegoría y realismo: el problema del estilo en Borges", Revista de crítica literaria latinoamericana, 20, 39, 141-156.

Јакобсон 1966: Р. Јакобсон, Лингвистика и поетика, Београд: Нолит.

Кастељанос 2012: P. Castellanos, "La emoción ante las palabras: teoría de Borges sobre el lenguaje poético", Literatura: teoría, historia, crítica, 14, 2, 31-65.

Ковачевић 2000: М. Ковачевић, Стилистика и граматика стилских фигура, Крагујевац: Кантакузин.

Медведев 1976: П. М. Медведев, Формални метод у науции о књижевности: критички увод у социолошки поетику, Београд: Нолит.

Павловић-Самуровић 1993: Љ. Павловић-Самуровић, Лексикон хиспаноамеричке къижевности, Београд: Савремена администрација. 
Рамирес-Пимијента 2005: J. C. Ramírez-Pimienta, "Escapando a la realidad: hacia un deslinde de lo fantástico", Revista de crítica literaria latinoamericana, 31/62, 163-180.

Poac 2001: D. Roas, "La amenaza de lo fantástico", David Roas, Teorías de lo fantástico, Madrid, Arco/libros, 7-44.

Poac 2011: D. Roas, Tras los límites de lo real: una definición de lo fantástico, Madrid: Omagraf.

Саватер 2002: F. Savater, "Borges, poetafilósofo", Archipiélago, 50, 45-50.

Солдатић 2002: Д. Солдатић, Прилози за теоријуновогхиспаноамеричког романа, Београд: Филолошки факултет; Крагујевац: Нова Светлост.

Тињанов 1976: Ј. Тињанов, Структура уметничког текста, Београд: Нолит.

Тодоров 2010: Ц. Тодоров, Увод у фантастичну књижевност, Београд: Службени гласник.

Фајн 2000:R. Fine, El concepto de desautomatizacićon en literatura: su ejemplificacićon en el Aleph de Jorge Luis Borges, Gaithersburg: Hispćamerica.

Хил Гереро 2008: H. Gil Guerrero, Poética narrativa de Borges, Madrid, Frankfurt: Iberoamericana-Vervuert.

Џексон 1986: R. Jackson, Fantasy: literatura y subversión, Buenos Aires: Catálogos Editora.

Џексон 2001: "Lo oculto de la cultura", David Roas (coord.), Teorías de lo fantástico, Madrid, Arco/libros, 141-153.

Шкловски 1969:В. Шкловски, Ускрснуће речи, Загреб: Свијет сувремене стварности.

\section{FIGURES OF HARMONIC CONTRADICTION AS DEVICES OF STYLISTIC EXPRESSION IN FANTASTIC REALISM OF JORGE LUIS BORGES}

\section{Summary}

The objective of this paper is to examine some of the main stylistic devices in Borges's short stories, that belong to the fantastic realism literature. As the main objective of these stories is to provoke strangeness and instability in the reader's perception of reality, the paper will tend to show that the basics of Borges's style is in the formalist method of estrangement and deautomatization. One of the hypothesis of the paper is that the effect of the fantastic depends on the effect of strangeness which relies on the juxtaposition of semantically contradictory notions. Second hypothesis is that bringing together semantically 
different notions, and through the usage of oxymoron and paradox, creates the effect of the fantastic realism and refers to the fantastic realm of the reality. This way the broadened combination of the linguistic signs, as well as of their semantic fields and the establishing of the logical relations between antonyms, refers to the basics of the Borges's fantastic realism - broadening the reality and its enrichment by human imagination. For the investigation of these hypothesis, the cases of oxymoron and paradox will be analyzed in selected stories from collections Ficciones and El Aleph.

Key words: fantastic realism, estrangement, Borges, paradox, oxymoron 